\title{
Transmission of Kashmir bee virus by the ectoparasitic mite Varroa destructor $^{1}$
}

\author{
Yanping CheN ${ }^{a *}$, Jeffery S. PetTis ${ }^{\mathrm{a}}$, Jay D. EvAns ${ }^{\mathrm{a}}$, Matthew KRAMER ${ }^{\mathrm{b}}$, \\ Mark F. FELDLAUFER ${ }^{\text {a }}$ \\ ${ }^{a}$ USDA, Agricultural Research Service, Bee Research Laboratory, Bldg. 476; BARC-East, \\ Beltsville MD 20705, USA \\ b USDA, Agricultural Research Service, Biometrical Consulting Services, Bldg. 005; BARC-West, \\ Beltsville MD 20705, USA
}

(Received 24 June 2003; revised 25 November 2003; accepted 12 December 2003)

\begin{abstract}
The ability of the parasitic mite Varroa destructor to transmit Kashmir bee virus (KBV) to the Western honey bee (Apis mellifera) was investigated by exposing pupae from a KBV-negative colony to varying numbers of adult female mites from KBV-positive colonies. After five days, the virus status of pupae and the mites was determined by RT-PCR. There was a significant relationship between KBVpositive pupae and exposure to KBV-positive mites. No pupae were virus-positive when all the mites introduced into a given cell subsequently tested negative. Mites testing positive for KBV transmitted virus about $70 \%$ of the time. The percentage of KBV-positive $V$. destructor in a given cell also increased significantly, suggesting virus-free mites became virus-positive by cohabiting in the same cell with viruspositive mites, and we calculated the mite-to-mite transmission rate as $51 \%$. There was $100 \%$ sequence identity of 415 bp KBV fragment amplified from bee pupae and mites, reflecting two isolates of the same virus source and supporting the conclusion of virus transmission from mite to bee pupae.
\end{abstract}

\section{Kashmir bee virus / transmission / Varroa destructor / RT-PCR}

\section{INTRODUCTION}

Kashmir bee virus (KBV) of honey bees is an RNA virus in the newly-established family Dicistroviridae (Mayo, 2002). KBV was first isolated from adult Western honey bees (Apis mellifera L.) that were experimentally inoculated with an extract prepared from the Indian honey bee A. cerana Fabricius originating from Kashmir, hence the designation (Bailey and Woods, 1977). Since the virus' initial description, strains of KBV have been reported on at least four continents (Anderson, 1985, 1990; Anderson and Gibbs, 1988; Allen and Ball, 1995; Bruce et al., 1995; Hung et al., 1995). While KBV is thought to be one of the most vir- ulent honey bee viruses under laboratory conditions (Allen and Ball, 1995), questions still remain as to the virus' importance in field colonies (Anderson, 1991).

Because the parasitic mite Varroa destructor Anderson and Trueman feeds and moves regularly between brood and adult bees, these mites have the potential to act as either biological or mechanical vectors of bee viruses. While bee viruses were noticed prior to the arrival of V. destructor in A. mellifera populations (Bailey, 1976), viral disease outbreaks have often been reported to be associated with mite infestations. Levels of several other bee viruses, including acute bee paralysis virus (ABPV), slow paralysis virus (SPV), black queen cell

\footnotetext{
${ }^{1}$ Disclaimer: Mention of trade names or commercial products in this article is solely for the purpose of providing specific information and does not imply recommendation or endorsement by the U.S. Department of Agriculture.

* Corresponding author: chenj@ba.ars.usda.gov
} 
virus (BQCV), deformed wing virus (DWV), and cloudy wing virus (CWV) have been correlated with mite levels in colonies (Ball, 1985; Allen et al., 1986; Ball and Allen, 1988; Allen and Ball, 1996; Martin et al., 1998; Nordström et al., 1999; Bakonyi et al., 2002). Nevertheless, direct evidence for the role of mites in virus transmission is scant. A single study involving DWV provided strong circumstantial evidence that $V$. destructor is an effective vector of this virus in bee colonies (BowenWalker et al., 1999).

In this paper, we use molecular techniques to evaluate the ability of $V$. destructor to transmit KBV and present evidence that these mites are capable of transmitting virus to bee brood under experimental conditions. We also provide evidence of horizontal mite-to-mite acquisition of virus, presumably via a honey bee intermediary.

\section{MATERIALS AND METHODS}

\subsection{Virus status of honey bee colonies and $V$. destructor}

In order to conduct transmission experiments, we needed to identify honey bee colonies and mites that were infected with KBV and colonies that were virus-free. Immature and adult bees were sampled from 20 colonies maintained in Beltsville MD. A single brood frame was selected from each colony and brood (larvae and pupae) were randomly sampled by uncapping individual brood cells and transferring brood to individual microcentrifuge tubes with fine forceps. Any brood samples damaged in the process were discarded. Frames were labeled and returned to the original colonies. Adult bees were collected by shaking the frame and gently scraping worker bees into $50-\mathrm{mL}$ conical tubes. Twenty adults, larvae and pupae were collected per colony, and all samples were stored at $-80^{\circ} \mathrm{C}$ freezer for subsequent analyses. Throughout the collection of adult and immature bees, a visual observation of mite infestation in each colony was made and noted.

The virus status of each colony was determined by RT-PCR analyses of brood and adult bees. Five larvae, pupae and adult bees (from the 60 collected) were randomly selected from each colony. After transferring adult bee samples to individual eppendorf tubes, all samples were homogenized in $500 \mu \mathrm{L}$ TRIzol Reagent (Invitrogen; Carlsbad CA, USA) for RNA extraction according to the manufacturer's instructions. RNA samples were re-suspended in
DEPC-treated water in the presence of Ribonuclease Inhibitor (Invitrogen) and stored at $-80^{\circ} \mathrm{C}$ for further RT-PCR analysis. An Access RT-PCR system (Promega; Madison WI, USA) was used to screen for the presence of KBV in the samples. KBV-specific primer pairs (KBV-1: 5'-GATGAACGTCGACCTATTGA-3', KBV-2: 5'-TGTGGGTTGGCTATGAGTCA-3') based on Stoltz et al. (1995) were used to amplify a 415-bp DNA fragment. Amplification was performed by adding $500 \mathrm{ng}$ RNA in a total volume of $25 \mu \mathrm{L}$ reaction mixture containing $1 \mathrm{X}$ AMV/ Tfl reaction buffer, $0.2 \mathrm{mM}$ each dNTP, $1 \mu \mathrm{M}$ of each primer, $2 \mathrm{mM} \mathrm{MgSO}_{4}, 0.1$ unit AMV reverse transciptase, and 0.1 unit Tfl DNA polymerase. The RTPCR was performed under the following conditions: one cycle at $48{ }^{\circ} \mathrm{C}$ for $45 \mathrm{~min} ; 95^{\circ} \mathrm{C}$ for $2 \mathrm{~min}$; 40 cycles at $95^{\circ} \mathrm{C}$ for $30 \mathrm{~s}, 55^{\circ} \mathrm{C}$ for $1 \mathrm{~min}$, and $68^{\circ} \mathrm{C}$ for $2 \mathrm{~min} ; 68^{\circ} \mathrm{C}$ for $10 \mathrm{~min}$. Negative and positive controls were included in each run of RT-PCR reactions. Amplification products were analyzed by electrophoresis through $1 \%$ agarose gels containing $0.5 \mathrm{ug} / \mathrm{mL}$ ethidium bromide and viewed under UV light.

After these analyses, colonies in which larval, pupal and adult bees had virus were designated "KBV-positive". Colonies without detectable virus were designated "KBV-negative" and additional larvae, pupae and adults (5 each) from these colonies were analyzed two more times to verify their negative status. Mites from colonies that were identified as $\mathrm{KBV}$-positive were collected and analyzed for $\mathrm{KBV}$ in pooled groups of five, as described above. Virus-positive colonies infested with virus-positive $V$. destructor were designated as mite "donor" colonies. Virus-free colonies with no apparent $V$. destructor infestation were designated as mite "recipient" colonies.

\subsection{Transmission experiments}

Frames containing brood were removed from donor and recipient colonies and taken to the laboratory. Individual mites from the donor colony were collected with forceps and placed in a petri dish lined with damp filter paper. One, two, three or four of these mites were subsequently introduced into individual brood cells ( $\mathrm{n}=10$ cells/group) of the recipient colony by making a small incision in the wax brood capping with a scalpel and inserting the mites with a tapered brush. All cells were then re-sealed. Controls consisted of ten cells that received no mites, but were opened and re-sealed. All manipulated brood cells ( $n=50$; those with mites and controls) were marked with a white spot and the experimental recipient brood frames were then placed in an insect growth chamber at $30^{\circ} \mathrm{C}, 80-85 \% \mathrm{RH}$ for five days. Frames were kept in the insect growth chamber to prevent the possibility of worker bees in the recipient 
colonies rejecting the manipulated cells (BowenWalker, 1999).

After five days, recipient brood frames were removed from the incubator and all experimental cells were uncapped. Pupae were transferred to individual microcentrifuge tubes with forceps. All mites associated with each cell were collected individually, placed in microcentrifuge tubes and labeled accordingly. Any dead mites observed during the collection were also recorded at this time. The virus status of all recipient pupae and mites harvested from recipient pupal cells was determined by RT-PCR as described above. This protocol allowed us to determine the presence of virus associated with an individual pupa, as well as in any individual mite or mites associated with that particular pupa. Transmission experiments were repeated three times, and involved the uncapping of 150 cells and the transfer of a total of 300 mites.

\subsection{Sequencing}

The 415-bp KBV fragments amplified from the RNA samples of five virus positive mites and five virus-positive pupae were purified individually with a Wizard ${ }^{\circledR}$ PCR Preps kit (Promega; Madison WI) and cloned into a TOPO cloning vector (Invitrogen). The nucleotide sequences of the RT-PCR fragments were determined using an Applied Biosystems Model 3100 DNA Sequencer (Foster City CA, USA) from both forward and reverse directions. Sequencing data from pupae and mites were analyzed using Pairwise BLAST (Tatusova and Madden, 1999).

\subsection{Statistical analysis}

To determine if mites transmit viruses we used a two by three contingency table analysis on the frequencies of positive and negative bee pupae, crossclassified by one of three mite exposure groups: (i) no mites in a pupal cell (controls); (ii) no virus-positive mites in a pupal cell; and (iii) at least one virus-positive mite in a pupal cell. We tested for independence using a chi-square test.

To examine the effect of multiple mite introductions on brood, the proportion of positive brood for each of the three replicates was arcsine transformed to meet the homogeneity of variance assumption for ANOVA. These transformed proportions were analyzed using Proc GLM (SAS, 1999), with the number of introduced mites as a class variable, and then tested to determine which transformed proportions differed using the Tukey adjustment for multiple comparisons. The transformed proportions were weighted by the number of brood examined per replicate in the analysis.
We used similar methodology to determine whether the proportion of virus-positive mites (determined five days after their introduction) increased with multiple introductions as would be expected if viruspositive mites transmit virus to cohabiting, virusfree mites. To jointly estimate the two parameters, i.e., the initial proportion of virus-positive mites $(p)$ and the probability that a virus-free mite would become virus-positive by cohabiting with one or more virus-positive mites $(t)$ of such a model, we found parameter values that minimized the squared difference between the average number of mites found to be positive in cells and a function generalized from a binomial expansion of expected counts, as described below, using the Mathematica program (Wolfram, 1996).

For one introduced mite, no transmission to another mite could occur, so we represent the contribution of these cells to the function as $\left(p-x_{1}\right)^{2}$, where $x_{1}$ is the observed proportion of virus-positive mites in one mite introductions. For two mite introductions, cells with positive mites could occur from either having had one or two positive mites introduced (recall that virus status of mites is unknown at introduction). In cells where both mites tested positive at the end of the experiment, either two positive mites could have been introduced or just one, but the first transmitted virus to the second. The expected number of positive mites in two mite introductions can be calculated as $2 p^{2}+2 p(1-p)(1+t)$, where $2 p^{2}$ accounts for cells where two virus-positive mites were introduced, and $2 p(1-p)(1+t)$ accounts for cells where one virus-positive and one virus-negative mite were introduced. If transmission never occurred, the expected number of positive mites, based on the binomial distribution, would be $2 p(1-$ $p$ ). Since we allow for transmission, this term is inflated by the factor $1+t$ because a proportion $t$ of virus-free mites becomes virus-positive. The contribution of two mite introductions to the function is then $\left(2 p^{2}+2 p(1-p)(1+t)-x_{2}\right)^{2}$, where $x_{2}$ is the average number of virus-positive mites in two mite introductions. Similar reasoning was used to calculate expressions, also generalized from the binomial distribution, for the expected number of virus-positive mites when three mites were introduced (algebraically simplified to $\left.3 p((p-1) t-1)^{2}\right)$ and when four mites were introduced $\left(-4 p((\mathrm{p}-1) t-1)^{3}\right)$.

\section{RESULTS}

\subsection{Virus status of honey bee colonies and Varroa}

Of the 20 bee colonies originally sampled and tested for virus by RT-PCR, three colonies 


\section{A. Mite Donor Colony}

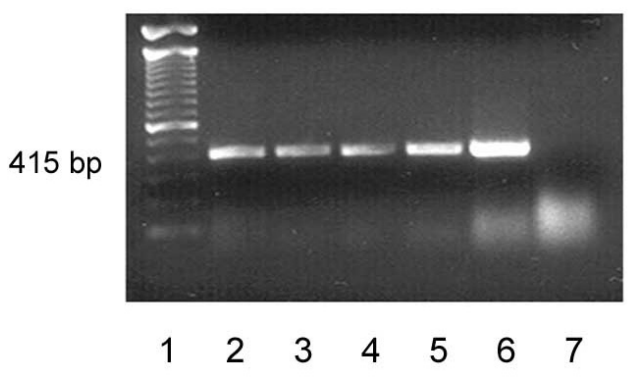

\section{B. Recipient Colony}

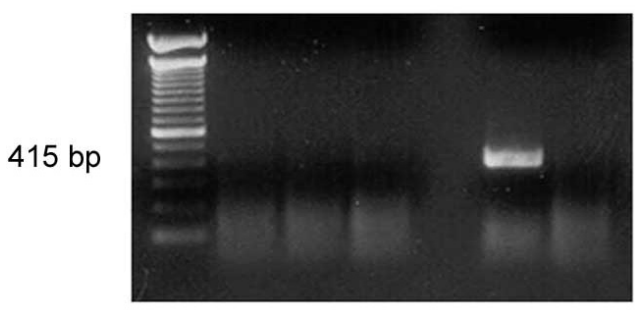

\section{$\begin{array}{lllllll}1 & 2 & 3 & 4 & 5 & 6 & 7\end{array}$}

Figure 1. Virus status of "mite donor" colony (A) and "recipient" colony (B). Total RNA was extracted from samples of adult, larval, and pupal bees, and from Varroa ( $\mathrm{n}=5$ /group), and all samples were subjected to RT-PCR. Lane labels are the same for "A" and "B". Lane 1 = $100 \mathrm{bp}$ DNA ladder; Lane 2 = RNA from adult bees; Lane $3=$ RNA from larvae; Lane $4=$ RNA from pupae; Lane $5=$ RNA from Varroa destructor ("A" only); Lane $6=$ positive control (previously identified KBV positive sample); Lane 7 = negative control (without template). The band at $415 \mathrm{bp}$ indicates the presence of KBV.

contained adults, larvae and pupae that were positive for KBV, while adult and brood bees from the remaining 17 colonies tested negative for KBV. These three virus-positive colonies along with a single virus-negative colony were selected for subsequent experiments. Mites collected and analyzed by RT-PCR for KBV from the three virus-positive colonies also tested positive for virus, so these colonies were designated "mite donor" colonies. Interestingly, no mites were found in the virus-negative colony after the uncapping of over 600 cells, and this colony was designated as the "recipi- ent" colony. The virus status of bees and mites from a representative "mite donor" colony and bees from the "recipient" colony are shown in Figure 1.

\subsection{Transmission of KBV to bee brood by $V$. destructor}

There was a significant relationship $\left(\chi^{2}=\right.$ $75.90 ; P<0.0001$; d.f. $=2)$ between the number of KBV-positive pupae and exposure to KBVpositive mites (Tab. I). No pupae in the control group (no mites) tested KBV-positive, nor did any pupae test positive when all of the mites introduced into a given cell subsequently tested negative. The only pupae that tested positive for KBV were those exposed to at least one KBV-positive mite. Not all positive mites, however, successfully transmitted virus to brood. In those cells where only a single mite, later determined to be virus-positive, was introduced, $70 \%$ of pupae tested virus-positive (Tab. II).

There was a significant difference $(\mathrm{F}=$ 25.65; $P=0.0002$ ) between the percentage of bee pupae found to be KBV-positive and the number of mites the pupae were exposed to (Tab. II). On average, $26 \%$ of the pupae exposed to one mite tested positive for KBV after five days. The percentage of KBV-positive pupae increased to approximately $35 \%$, $67 \%$, and $96 \%$ when exposed to 2,3 , or 4 mites, respectively. A representative RT-PCR result obtained from one of the transmission experiments is shown in Figure 2.

\subsection{Acquisition of KBV by $V$. destructor}

The percentage of KBV-positive mites also increased significantly $(\mathrm{F}=17.74 ; P=0.0007)$ as more mites were introduced into a cell (Tab. II), suggesting that virus-free mites become viruspositive by cohabiting in the same cell with KBV-positive mites. While $37.0 \%$ of the mites involved in the single mite introductions were determined to be KBV-positive five days after their introduction into cells, this percentage rose to almost $60 \%$ in the two-mite introductions and to $72.2 \%$ and $93.8 \%$ in the three- and four-mite introductions, respectively. Based on our generalization of the binomial distribution, we were able to estimate the mite to mite transmission rate (the probability of a virus-free 
Table I. Transmission of KBV to honey bee pupae by Varroa destructor ${ }^{1}$.

\begin{tabular}{lcc}
\hline Mite Status & Nb virus positive pupae & No. of virus negative pupae \\
\hline Control (no mites) & 0 & 30 \\
When all mites in a cell were negative & 0 & 27 \\
When at least 1 mite in a cell was positive & 55 & 19 \\
\hline
\end{tabular}

${ }^{1}$ Honey bee pupae (presumed to be virus-free) were exposed to $0-4$ mites by uncapping cells and introducing mites. After resealing, frames containing the manipulated cells were incubated at $30^{\circ} \mathrm{C}$. After five days, the virus status of all pupae and mites collected from recipient pupal cells was determined by RT-PCR (see Material and Methods).

Table II. Percentage of KBV-positive brood and Varroa from transmission experiments ${ }^{1}$.

\begin{tabular}{|c|c|c|c|c|}
\hline $\begin{array}{l}\mathrm{Nb} \text { mites } \\
\text { introduced }\end{array}$ & $\begin{array}{l}\mathrm{Nb} \text { pupae } \\
\text { examined }^{2}\end{array}$ & $\%$ infected brood ${ }^{3}$ & $\%$ infected mites ${ }^{4}$ & $\begin{array}{l}\text { Ave. No. of infec- } \\
\text { ted mites/cell }\end{array}$ \\
\hline 0 & 30 & 0 & na & na \\
\hline 1 & 27 & $25.9^{\mathrm{a}}(11.7,43.1)$ & $37.0^{\mathrm{x}} \quad(22.8,52.4)$ & 0.37 \\
\hline 2 & 26 & $34.6^{\mathrm{ab}}(18.3,52.9)$ & $59.6^{x y} \quad(43.9,74.6)$ & 1.19 \\
\hline 3 & 24 & $66.7^{\mathrm{b}}(48.5,83.9)$ & $72.7^{y} \quad(56.8,85.8)$ & 2.17 \\
\hline 4 & 24 & $95.8^{\mathrm{c}} \quad(90.9,99.3)$ & $(86.4,99.8)$ & 3.75 \\
\hline
\end{tabular}

${ }^{1}$ Honey bee pupae (presumed to be virus-free) were exposed to 0-4 mites by uncapping cells and introducing mites. After resealing, frames containing the manipulated cells were incubated at $30^{\circ} \mathrm{C}$. After five days, the virus status of all pupae and mites collected from recipient pupal cells was determined by RT-PCR (see Material and Methods).

${ }^{2}$ A total of 30 pupae were exposed in each group ( 3 replicates; 10 pupae/replicate). Numbers less than 30 indicate damage by wax moth during the five day incubation period; no pupal or mite samples were collected from those cells.

${ }^{3}$ Percentage of infected pupae with lower and upper 95\% confidence interval in parentheses. Letter superscripts indicate significant difference using the Tukey adjustment for multiple comparisons.

${ }^{4}$ Percentage of infected Varroa with lower and upper 95\% confidence intervals in parentheses. Letter superscripts indicate significant difference using the Tukey adjustment for multiple comparisons; "na" = not applicable.

mite testing positive by cohabiting on a host with one or more virus-positive mites) as $51 \%$. From minimizing the same function, we also obtained $44 \%$ as an estimate of the initial (or population) percentage of virus-positive mites. This number is close to our observed value of $37 \%$ positive mites in single mite introductions and well within expected sampling error.

\subsection{Sequence analysis of the KBV amplicon}

Comparison of the 415 bp KBV fragments amplified from bee pupae and mites revealed that the KBV fragment from both shared $100 \%$ sequence identity.

\section{DISCUSSION}

The epidemiology of vector-borne diseases depends on the natural history and population dynamics of appropriate vectors and their transmission efficiencies. While $V$. destructor has long been proposed as a potential vector for honey bee viruses (Batuev, 1979; Ball and Allen, 1988; Kulincevic et al., 1990; Allen and Ball, 1996), very few studies have provided direct evidence, and only a single laboratory study has offered quantitative estimates for the efficiency of transmission (Wiegers, 1988). Two field trials, though, have shown a strong association between mite and virus presence. Bowen-Walker et al. (1999) provided strong circumstantial evidence that $V$. jacobsoni 


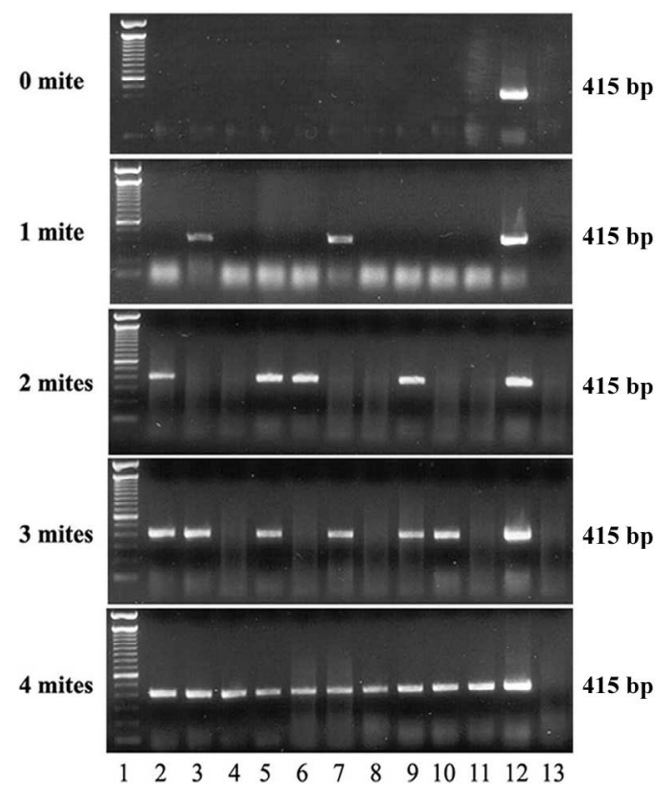

Figure 2. Representative RT-PCR results obtained from one transmission experiment involving bee pupae presumed to be KBV-negative and Varroa presumed to be KBV-positive. Total RNA was extracted from pupae exposed to varying numbers $(0-4)$ of mites. All samples were subjected to RTPCR. The number of mites introduced in each experimental group is indicated on the left of gel. Lane $1=$ 100 bp DNA ladder; Lanes 2-11 = RNA from individual pupae $(n=10)$ after five days exposure to mites; Lane 12 = positive control (previously identified KBV positive sample); Lane $13=$ negative control (without template). The band at 415 bp indicates the presence of KBV.

(= destructor Anderson and Trueman, 2000) was an effective vector of DWV in the bee colonies. Mites apparently obtained DWV from infected bees then transmitted the virus to uninfected bees, which showed either morphological deformities or higher mortality. Bakonyi and colleagues (2002) revealed that colonies both infected with ABPV and experiencing severe losses were also infested with mites.

In our study, we present experimental evidence that $V$. destructor can transmit $\mathrm{KBV}$ to their honey bee hosts. Mites collected from a virus-positive colony proved to be effective vectors of KBV. Based on the percentage of virus-positive mites in single mite introductions $(37 \%)$ and the percentage of positive brood in these instances (25.9\%), we calculated a transmission efficiency of $70 \%$. Since pupae were only exposed to mites for five days, this could be an underestimate. Our transmission efficiency is similar to that reported by Wiegers (1988), who used bee pupae experimentally infected with acute bee paralysis virus.

We also observed an increase in the proportion of virus-positive pupae as more mites were added to an individual cell, culminating in an infection rate of almost $96 \%$, when four mites were in a single cell. There are several possibilities that could account for this phenomenon. In the simplest case, where the probability of virus transmission from an individual mite is independent of the number of mites introduced, pupal infection rates would depend only on the probability that no virus-positive mites were introduced. In this case, the proportion of positive pupae would follow the expression $1-m^{n}$, where $m$ is the probability that an introduced mite (whether positive or not) does not transmit the virus and $n$ is the number of introduced mites. The biggest changes in this expression would occur for small $n$, while only a relatively small change would be seen when $n$ is large. Since our data show a significant difference in the proportion of virus-positive pupae from three to four introduced mites, the independence model is probably too simple. An alternative possibility, and one more consistent with the data we collected, involves a scenario where introducing more mites makes the pupa more susceptible to the virus. In this case, as more mites are introduced, the proportion of positive pupae might increase as under independence until there were sufficient mites to stress the pupa, when larger jumps in the proportion, not consistent with the independence model, would occur. While our experiment was not designed to determine the factors affecting pupal susceptibility to mite transmission, elucidating this relationship is necessary as part of understanding the etiology of this disease's effect in bee colonies.

We also provide evidence that virus-free mites can acquire virus by sharing a cell with one or more virus-positive mites, and have calculated a mite-to-mite transmission or acquisition rate of $51 \%$. As with pupae, this could be an underestimate, as mites were exposed to pupae and other mites for only five days, not the entire pupal developmental period. Two different mechanisms may explain mite to mite 
acquisition of virus. Viruses could be transmitted by direct contact (contamination) between affected and unaffected mites. However, this mechanism seems unlikely, since viruses are intracellular parasites and arthropod vectors of plant and animal viruses rarely transmit pathogens among themselves without a host intermediary. A more likely scenario is where a virus-positive mite infects a pupal bee and virus-free mites subsequently become infected while feeding on the hemolymph of this bee. This has previously been suggested by Martin (2001) with DWV. While his work deals with the acquisition of virus by mite offspring, and ours by adult mites, the principle is the same acquisition of virus through a host intermediary.

To model how viral infections are spread through a bee colony, the effects of various factors need to be determined. We have estimated two important parameters in this system, the transmission efficiency of virus from mite to pupal bee, and the transmission rate of the virus from mite to mite, presumably through a host intermediary. In combination with $V$. destructor population studies (Martin, 1998, 2001; Branco et al., 1999), these parameters can help better predict the conditions that allow viruses to spread and impact colony health. Our study also demonstrates the exceptional power of molecular techniques in viral investigations. The ability to detect virus in individual bees and mites should prove of great use in future studies directed at the epidemiology of honey bee viruses.

\section{ACKNOWLEDGMENTS}

The authors wish to express their sincere gratitude to Ms. Michele Hamilton and Mr. Barton Smith, Jr. for providing excellent technical assistance.

Résumé - Transmission du virus du Cachemire de l'abeille par l'acarien ectoparasite Varroa destructor. Une étude a été menée pour évaluer la capacité de l'acarien Varroa destructor Anderson and Trueman à transmettre le virus du Cachemire de l'abeille (KBV) à l'Abeille domestique (Apis mellifera L.). A l'aide de techniques moléculaires sensibles (RT-PCR) on a identifié les colonies dans lesquelles les abeilles et les acariens étaient porteurs du virus et d'autres colonies ont été identifiées comme non porteuses du virus (Fig. 1) Un nombre variable d'acariens d'une colonie porteuse du virus a été transféré dans les cellules de nymphes d'une colonie non porteuse du virus. Cinq jours plus tard, l'état viral des nymphes et des acariens auxquels les nymphes avaient été exposées a été déterminé par RT-PCR. On a trouvé une relation significative entre les nymphes porteuses du KBV et l'exposition aux acariens porteurs du KBV. En outre, aucune nymphe du groupe témoin (sans acarien) n'a été détectée positive au virus et aucune nymphe n'a été détectée positive au virus quand tous les acariens introduits dans une cellule donnée avaient été détectés négatifs (Tab. I). Les seules nymphes qui ont été détectées positives au KBV ont été celles exposées à au moins un acarien porteur du KBV. D'après le pourcentage d'acariens infectés lorsqu'un seul acarien était introduit (37\%) et le pourcentage de couvain infecté dans ces cas-là $(25,9 \%)$, nous avons calculé que l'efficacité de transmission était de $70 \%$. Le pourcentage d'acariens infectés dans une cellule donnée a augmenté significativement parallèlement au nombre d'acariens introduits, ce qui suggère que les acariens non infectés devenaient porteurs du virus lorsqu'ils cohabitaient dans une même cellule avec des acariens infectés (Tab. II). Lorsqu'on a introduit quatre acariens dans une cellule donnée, presque $94 \%$ des acariens ont été détectés positifs au KBV. Nous avons calculé que le taux de transmission entre acariens était de $51 \%$

\section{virus du Cachemire de l'abeille / transmission /} Varroa destructor / RT-PCR / Apis mellifera

Zusammenfassung - Übertragung des Kaschmir Bienenvirus durch die ektoparasitische Milbe Varroa destructor. Die Fähigkeit der parasitischen Milbe Varroa destructor Anderson and Trueman zur Übertragung des Kaschmir Bienenvirus (KBV) wurde untersucht. Anhand sensitiver molekularer Methoden (RT-PCR) wurden Völker bestimmt, in denen Bienen und Milben viruspositiv waren; andere Völker wurden als Virus-negativ bestimmt (Abb. 1). Unterschiedliche Anzahlen von Milben aus einem Virus-positiven Volk wurden in Puppenzellen des Virus- negativen Volkes übertragen. Fünf Tage später wurde der Virusbefund der einzelnen Puppen und der einzelnen Milben, denen diese Puppen ausgesetzt waren, anhand von RT-PCR bestimmt. Es bestand eine signifikante Beziehung zwischen KBV-positiven Puppen und dem Besatz mit KBV-positiven Milben. Weiter zeigten weder die Puppen in der Kontrollgruppe (keine Milben) einen positiven Befund noch die Puppen, bei denen alle in die Zellen eingebrachten Milben Virus-negativ waren (Tab. I). Die einzigen Puppen mit positivem Befund waren diejenigen, die mindestens einer Virus-positiven Milbe ausgesetzt waren. Aus dem Prozentsatz infizierter Milben in mit einer einzelnen Milbe infizierten Zellen (37\%) und dem Prozentsatz infizierter Brut in diesen Zellen $(25,9 \%)$ berechneten wir eine Übertragungsrate von $70 \%$. Der Prozentsatz infizierter Milben in den Zellen nahm signifikant zu, 
wenn mehrere Milben zugesetzt wurden. Dies weist darauf hin, dass Milben Virus-positiv werden, wenn sie sich zusammen mit infizierten Milben in der gleichen Zelle befinden. (Tab. II). Von den einzeln eingesetzten Milben waren $37 \%$ Virus-positiv, bei vier eingesetzten Milben waren dies $94 \%$. Wir berechneten hieraus eine Übertragungsrate von Milbe zu Milbe von $51 \%$.

\section{Kaschmir Bienenvirus / Übertragung / Varroa destructor / RT-PCR}

\section{REFERENCES}

Allen M.F., Ball, B.V. (1995) Characterization and serological relationships of strains of Kashmir bee virus, Ann. Appl. Biol. 126, 471-484.

Allen M.F., Ball B.V. (1996) The incidence and world distribution of honey bee viruses, Bee World 77, 141-162.

Allen M.F., Ball B.V., White R.F., Antoniw J.F. (1986) The detection of acute paralysis virus in Varroa jacobsoni by the use of a simple indirect ELISA, J. Apic. Res. 25, 100-105.

Anderson D.L. (1985) Viruses of New Zealand honey bees, N.Z. Beekeep. 188, 8-10.

Anderson D.L. (1990) Pests and pathogens of the honey bee (Apis mellifera) in Fuji, J. Apic. Res. 29, 53-59.

Anderson D.L. (1991) Kashmir bee virus - a relatively harmless virus of honey bee colonies, Am. Bee J. 131, 767-770.

Anderson D.L., Gibbs A.J. (1988) Inapparent virus infections and their interactions in pupae of the honey bee (Apis mellifera Linnaeus) in Australia, J. Gen. Virol. 69, 1617-1625.

Anderson D.L., Trueman J.W.H. (2000) Varroa jacobsoni (Acari: Varroidae) is more than one species, Exp. Appl. Acarol. 24, 165-189.

Bailey L. (1976) Viruses attacking the honey bee, Adv. Virus Res. 20, 271-304.

Bailey L., Woods R.D. (1977) Two more small RNA viruses from honey bees and further observations on sacbrood and acute bee-paralysis virus, J. Gen. Virol. 37, 175-182.

Bakonyi T., Farkas R., Szendroi A., Dobos-Kovács M., Rusvai M. (2002) Detection of acute bee paralysis virus by RT-PCR in honey bee and Varroa destructor field samples: rapid screening of representative Hungarian apiaries, Apidologie 33, 63-74.

Ball B.V. (1985) Acute Paralysis Virus isolates from honeybee colonies infested with Varroa jacobsoni, J. Apic. Res. 24, 115-119.

Ball B.V., Allen M.F. (1988) The prevalence of pathogens in honey bee colonies infested with the par- asitic mite Varroa jacobsoni, Ann. Appl. Biol. 113, 237-244.

Batuev Y.M. (1979) New information about virus paralysis, Pchelovodstvo 7, 10-11 [in Russian].

Bowen-Walker P.L., Martin S.J., Gunn A. (1999) The transmission of deformed wing virus between honey bees (Apis mellifera L.) by the ectoparasitic mite Varroa jacobsoni Oud., J. Invertebr. Pathol. 73, 101-106.

Branco M.R., Kidd N.A.C., Picard R.S. (1999) Development of Varroa jacobsoni in colonies of Apis mellifera iberica in a Mediterranean climate, Apidologie 30, 491-503.

Bruce W.A., Anderson D.L., Calderone N.W., Shimanuki H. (1995) Survey for Kashmir bee virus in honey bee colonies in the United States, Am. Bee J. 135, 352-355.

Hung A.C.F., Adams J.R., Shimanuki H. (1995) Bee parasitic mite syndrome (II). The role of Varroa mite and viruses, Am. Bee J. 135, 702-704.

Kulincevic J., Ball B., Mladjan V. (1990) Viruses in honey bee colonies infested with Varroa jacobsoni: first findings in Yugoslavia, Acta Vet. 40, 37-42.

Martin S.J. (1998) A population dynamic model of the mite Varroa jacobsoni Oud., J. Invertebr. Pathol. 73, 101-106.

Martin S.J. (2001) The role of Varroa and viral pathogens in the collapse of honey bee colonies: A modelling approach, J. Appl. Ecol. 38, 10821093.

Martin S., Hogarth A., van Breda J., Perrett J. (1998) A scientific note on Varroa jacobsoni Oudemans and the collapse of Apis mellifera L. colonies in the United Kingdom, Apidologie 29, 369-370.

Mayo M.A. (2002) Virus taxonomy - Houston 2002 , Arch. Virol. 147, 1071-1076.

Nordström S., Fries I., Aarhus A., Hansen H., Korpela S. (1999) Virus infections in Nordic honey bee colonies with no, low or severe Varroa jacobsoni infections, Apidologie 30, 475-484.

SAS Institute Inc. (1999) SAS/STAT User's Guide, Version 8. SAS Institute Inc. Cary NC.

Stoltz D., Shen X.-R., Boggis C., Sisson G. (1995) Molecular diagnosis of Kashmir bee virus infection, J. Apic. Res. 34, 153-160.

Tatusova T.A., Madden T.L. (1999) Blast 2 sequences - a new tool for comparing protein and nucleotide sequences, FEMS Microbiol. Lett. 174, 247-250.

Wiegers F.P. (1988) Transmission of honeybee viruses by Varroa jacobsoni Oud., in: Cavalloro R. (Ed.), European Research on Varroatosis Control, A.A. Balkema, Rotterdam, pp. 99-104.

Wolfram S. (1996) The Mathematica Book, 3rd ed., Wolfram Media/Cambridge University Press, Champaign, IL. 